\title{
Does Aid Improve Governance in Developing Countries? Different Effects by Multi-Dimensional Governance*
}

\author{
Ji Woong Yoon** and Eunju Kim***
}

\begin{abstract}
This paper examines whether aid to developing countries has achieved the policy goals of international development, which have tended to place considerable emphasis on the improvement of governance in developing countries. Previous studies have explored this issue by conceptualizing governance in terms of one aspect or by conducting micro-level case studies. In contrast, in this paper we try to analyze the effect of aid on governance by suggesting a new conceptual framework that defines governance as made up of three partspolitical, administrative, and judicial sectors. Then we analyze the effects of aid on these three sectors at macro level using a panel analysis of 90 developing countries over the 10-year period from 2002 to 2011. We found that aid helped improve political and administrative governance but not judicial governance. Based on our results, we suggest that strategies for governance improvement need to focus on public administration, since this appears to be the sector that is most amenable to reform. In addition, considering that judicial reform requires a long-term outlook to accumulate social trust, we need to put more effort into genuinely understanding the context of developing countries and into promoting reform based on their unique historical and cultural backgrounds as well as their political and socioeconomic circumstances.
\end{abstract}

Keywords: aid, governance, aid effectiveness

* The theory and discussion section of this paper is partly based on the corresponding author's doctoral thesis at Seoul National University, Korea. However, the research question and data for analysis has been reconstructed and reanalyzed only for this study. This study was also made possible owing to of the sabbatical leave of the first author in fall 2014 from Kyung Hee University.

** Ji Woong Yoon is an associate professor in the Department of Public Administration at Kyung Hee University, Korea. E-mail: jiwoongy@khu.ac.kr

*** Eunju Kim, corresponding author, is a visiting fellow at the Centre for Study on Poverty and Social Justice, University of Bristol, U.K. E-mail: joanne0427@ hanmail.net.

Manuscript received April 21, 2015; out for review May 10, 2015; review completed June 10, 2015; accepted July 1, 2015.

The Korean Journal of Policy Studies, Vol. 30, No. 2 (2015), pp. 1-21.

(C) 2015 by the GSPA, Seoul National University 


\section{INTRODUCTION}

Since the 1990s governance reform has been thought to be crucial for economic development and poverty reduction in developing countries (Kaufmann et al., 1999). The international community has required recipient countries to improve their governance as a condition of receiving aid because they believe that poor performance in development is caused by inadequate governance. Such reform has been increasingly expanded in line with the implementation of the millennium development goals (MDGs), which puts a strong emphasis on "good governance" in developing countries. Since the mid-2000s it also has been widely accepted that aid effectiveness is determined by institutional environments (Burnside\& Dollar, 2000; Collier \& Dollar, 2002), and thus the state of governance has become an essential selection criterion for international aid. Not only international organizations such as the World Bank and the International Development Association (IDA) but also many bilateral donor agencies (e.g., the Netherlands and the Millennium Challenge Cooperation [MCC] of the United States) are using governance as a criterion in deciding whether or not to provide foreign aid to a given country (Joost, 2007; Knoll \& Zloczysti, 2012).

This trend is confirmed by the fact that the amount of aid disbursed to programs targeting governance improvement has steadily increased over the last 10 years. From 2002 to 2011, the total amount of aid disbursement for governance reform increased from USD $\$ 5$ billion to almost USD $\$ 18$ billion. The amount of aid for improving governance has been increasing faster than it has for other major sectors such as education and health (OECD Development Assistance Committee, n.d.). However, as good governance has become a buzzword in the international development, it has also been argued on the basis of empirical evidence that good governance does not necessarily lead to poverty reduction and economic development (Kwon \& Kim, 2014; Kwon, 2010). These doubts raise numerous questions regarding the relationship between governance and aid. Has the aid disbursed to improve governance in developing countries led to any concrete and notable changes? Or does it paradoxically aggravate governance by creating aid dependency and encouraging corruption in the recipients (Moyo, 2009)? As MDGs will expire in 2015, we need to reconsider these questions once again and ask whether the policy approach to development that has been in place for more than 15 years has accomplished its policy goals.

Previous studies have evaluated program via case studies at the micro level or have focused on just one variable that represents a certain aspect of governance, for example, rule of raw, bureaucratic efficiency, and control of corruption. In contrast, this paper tries to analyze the effect of aid on governance by suggesting a new conceptual framework that defines governance as comprised of three different dimensions-the political, 
administrative, and judicial and then decomposes aid amounts in terms of these dimensions and empirically examines the effect of the aid on the recipient's governance level. For these purposes, we constructed a data sample using 90 developing countries over the 10-year period from 2002 to 2011 . We try to provide empirical evidence showing how each dimension has been improved due to aid by using a multidimensional governance framework.

This paper is structured as follows. In the following section, we summarize the theoretical literature on the relationship between governance and aid. Then we present our empirical model and data analysis. And finally we conclude with policy implications for developing countries with respect to future global international development agendas.

\section{GOVERNANCE AND AID}

\section{From the Perspective of the Global North}

Governance has been seen as one of the most essential tools for national development ever since the concept was introduced into the field of development studies (Brinkerhoff \& Brinkerhoff, 2002; Brinkerhoff, 2008). Developmental state theorists in particular argue that the governance structure of developing countries is important in guiding the process of development (Johnson, 1999) and in helping actors secure a country's sustainable development (AbouAssi, 2010).

However, of the term "governance" has been used to mean different things by different researchers, leaving no end of controversy (Doornbos, 2001). Development studies has used the term as defined in the field of comparative politics and international relations, which is as the "management of the official and unofficial rules of political games," that is, the management of institutions (Hyden, 1999: 185). The discourses regarding governance in international development have drawn on new institutional economics. Douglas North (1990), for example, insists that economic growth and social development are possible when institutions are stabilized, and there have been numerous theoretical studies and empirical analyses on the relationship between institutional quality and economic growth. The point of focusing on the relationship between institutions and economic growth has been to support the lowincome countries' private markets (North, 1990). The idea is that if developing countries are equipped with good governance that guarantees property rights and reduces transaction costs, they can achieve market-centered economic growth. These two core components of new institutional economics-property rights and transaction costs 
(Choi, 2006) — have provided the theoretical background for a range of econometric studies that have tried to explain the causal relation between institutions and economic growth. Because the rule of law is believed to protect property rights and because controlling corruption is thought to help decrease transaction costs, most of these studies have chosen these two elements as proxy variables for governance (Acemoglu et al., 2001; Knack \& Keefer, 1995; Rodrik et al., 2004). However, discourses based on new institutional economics tend to focus on the issue of what the public sector should do to invigorate market mechanisms. In this context, normative or political discourse on the fundamental roles of a government or state is ruled out (Leftwich, 1994), and the notion of governance has only been invoked to the extent that it relates to the implementation of economic policies (Kim, 2013, 35-36).

\section{From the Perspective of the Global South}

Originally, the concept of governance was used to explain the changing role of the government while taking account at the same time of the various actors that participate in the development of the society (Brinkerhoff \& Brinkerhoff, 2002; Kettl, 2002). This understanding of governance is embedded in the elaboration of the new public service (NPS), which emphasizes a closer engagement between government, citizens, and communities in the development processes (Denhardt \&Denhardt, 2000; Denhardt \& Denhardt, 2007). In developed countries, governance refers to a new way of governing in which diverse actors participate in policy processes and in which the traditional role of states is diminished. Within the context of the new public management, governance refers to the capacity of government to steer society among various policy actors (Pierre \& Peters, 2000).

However, this notion of governance is difficult to apply to developing countries, because many developing or least developed countries are newly democratic countries where democracy has not yet been firmly rooted or fragile states that lack the commitment and capacity to carry out the fundamental functions of a country. A concept of governance for developing countries that takes into account rebuilding nations is thus needed, rather than one that addresses the problems that arise as nations decline. Therefore, in an effort to clarify the concept of governance from the perspective of global South, this paper defines "governance" as "a state's capability to manage all of the key institutions in the political, administrative and judicial dimensions." (Kim, 2013, 41). It refers to the institutional capacity the state requires to play a pivotal role in economic and national development and to carry out its political, administrative and judicial functions. 


\section{Aid Programs for Governance Reform}

To examine the plausibility of a causal relationship that between aid and progress in governance, we first need to take a look at the kind of aid programs that have been pursued to improve governance during the last several decades. "Good governance" has been a main concern of international development cooperation since the early 1990s. A 1989 World Bank report entitled "Sub-Saharan Africa: From Crisis to Sustainable Growth" pointed to a lack of governance as the major reason for the underdevelopment of developing countries. In a 1997 report entitled "World Development Report: The State in a Changing World," the World Bank listed the areas of governance that had to be reformed and outlined specific institutional improvement tasks. It suggested 45 ways to improve governance in the 1997 report, and the list of reform strategies grew to 116 in a 2002 report. It recommended systems for fair and transparent elections and for adequate delivery of government services, rules for instilling fiscal discipline, methods for establishing legal and regulatory frameworks, and so on (World Bank, 2001, 274-275). Although the World Bank's recommendations should have been apolitical or technocratic because international financial institutions are prohibited from intervening in domestic political issues, its reform agenda list was largely driven by the ideology of neoliberalism. This is reflected in its urging that recipient countries make public sector reform, control over public spending, and privatization part of their medium-term development plans or poverty reduction strategy papers (PRSPs).

For example, in the early 2000s, Tanzania was been encouraged to promote public finance reform and in answer to that recommendation introduced the Tanzania Revenue Authority, an integrated financial management system, a medium-term expenditure framework, and a public expenditure review, among other reforms. It subsequently was deemed the best performer in governance reform among African countries (Utz, 2007). It received a higher score than neighbor countries in the area of macroeconomic management, fiscal policy, and debt policy in 2005 and 2006 from in an assessment conducted by the World Bank. Similar policies calling for civil service reform, public finance management reform, legal sector reform, and accountability, transparency, and integrity programs were imposed on other developing countries as well (Gray and Khan, 2010)

However, just as the theories of governance that have held sway in discussions of governance improvement in developing countries emanate largely from the global North, the practice in the policy field has been dominated by donor agencies, which are primarily located in the global North. The level of governance in a given developing country, for example, has been evaluated according to global standards that do not take the specific context of global South into account (AbouAssi, 2010; Brinkerhoff \& 
Brinkerhoff, 2010). Donors often shape the national policies and development processes of recipient countries by making aid conditional on a recipient's setting certain policy goals (Escobar, 1995). For example, donors expect the results of their aid to be quick and highly visible, which may set developing countries back (Dichter, 2003; Easterly, 2006; Unsworth, 2009). Donors also put strong emphasis on fiscal management in order to secure aid transparency. Owing to the imposition of such external demands, it is questionable whether aid for governance reform has actually improved the governance of developing countries according to their internal demands.

\section{Empirical Studies on Aid and Governance}

The effect of aid on governance in developing countries is a controversial topic. On the one hand, at least one empirical study claims the effect has been positive (Johnson and Zajonc, 2006). This research carried out a difference-in-differences analysis of six countries that received assistance from the MCC, an independent U.S. government foreign aid agency, by comparing them to other less developed countries that did not receive MCC assistance. The results showed that the assistance from the MCC helped the recipient countries to improve their governance. However, the study is limited by the fact that the experimental group comprised a mere six nations and that the control group was evaluated on the basis of the average values of all the other less developed countries. In addition, there have been many studies that evaluate aid programs at the micro level and that suggest particular ways of improving the governance in a given country, such as by creating donor-supported civic education programs designed to increase political awareness and empowerment even in context of political violence (Finkel, 2014)

On the other hand, another series of studies expresses concern about the attempt of international organizations to shift the center of public service from the government to civil society and financial markets under the name of governance reform, thereby weakening the governance capability of the government in low-income countries. For example, according to a study on developing countries in Latin America, good governance was imposed by international organizations, and many aid programs were carried out through civil society, which weakened the countries' capacity to implement governmental policy. Their administrative efficiency was weakened as well by following the requests to reform their administrative organization structures (Hewitt de Alcántara, 1998).

In addition to these case studies, there have been a few studies that have analyzed the overall effect of international development aid on governance indicators. Stephen Knack, who led empirical studies on the relationship between administrative capacity 
and economic growth, attempted an empirical analysis regarding aid and governance (Bräutigam \& Knack, 2004; Knack, 2001). The results of this analysis of 80 recipient countries and 32 sub-Saharan countries indicated that countries that had received more aid, paradoxically, worsened in governance (Knack, 2001). A study by Matthias Busse and Steffen Gröning (2009) similarly showed that foreign aid worsened receipent countries' governance. They claim that this result owes to aid dependency.

However, it is still inconclusive whether the effect of international aid on governance in less developed countries is positive or negative. The reason for the uncertainty is due to different sample, data, and method for the analysis. The number of countries included in these studies was not sufficiently large, nor was the period immediately following the imposition of good governance analyzed. Deborah Bräutigam and Stephen Knack (2004), for example, analyzed the average values of 32 sub-Saharan countries for 10 years, from the early 1980s to the early 1990s. A similar study was conducted by Busse and Gröning (2009), who increased the number of countries and extended the period, covering the 1980s through the beginning of the 2000s. However, the panel analysis does not include the period after 2000s when good governance assumed its place as a policy goal for less developed countries. In addition, previous studies often used the overall amount of aid as the explanatory variable; however, the overall amount of aid includes not only aid for the improvement of governance but also humanitarian aid and assistance for developing infrastructure and providing health care, among other things.

This paper thus aims to complement the existing literature on the effect of international aid on the governance of developing countries by using a larger sample of 90 countries and by decomposing the governance components into three parts and breaking out the amount of international aid awarded by sector.

\section{EMPIRICAL MODEL AND DATA}

\section{Empirical Model}

As explained in the previous section, governance is multidimensional. We are interested in whether the aid designated for a certain governance sector improves its performance and if so, to what extent, taking into account other factors that may be at work. We hypothesize that such aid will improve governance. To test this hypothesis, we develop a linear empirical model: 


$$
Y_{i t}=\beta_{0}+\left[\beta_{1}\left(X_{i t-1}\right)\right]+\beta_{2}\left(Z_{i t}\right)+\varepsilon_{i t}
$$

The dependent variable $\left(Y_{i t}\right)$ represents the governance of country $i$, which is broken down into political, administrative, and judicial sectors, at time $t$. The independent variable $\left(X_{i t-1}\right)$, that is, the amount of aid intended for governance improvement, is also analyzed with reference to the same three sectors. Because of the time gap between the provision of foreign aid and the implementation of aid programs, we compare the amount of assistance at the time $t-l$ with the status of governance at the time $t$. Other control variables $\left(Z_{i t}\right)$ include various socioeconomic factors such as the level of economic development, the level of trade openness, government expenditures, and population.

\section{Dependent Variables}

Since, in contrast to previous studies that used one certain variable such as rule of law or control of corruption as a proxy variable for governance, this study defines governance as multidimensional concept, we accordingly measure the level of governance as a dependent variable in each of the three sectors that comprise governance, analyzing the effect of the amount of aid designated for politics on political governance, the amount of aid intended for public administration on administrative governance, and the amount of aid afforded to the legal and judicial sector on judicial governance. We produced three models with three different dependent variables using the Worldwide Governance Indicator (WGI), which consists of six subcomponents of governance. We used three of these components that we see as indicative of the traits of multidimensional governance: voice and accountability, which refers to the assessment of political participation and responsibility and thus concerns governance in the area of political institutions; government effectiveness, which refers to the effectiveness of a government's policy making and implementation capacity and therefore to its capacity for administrative governance; and the rule of law, which refers to the degree to which a country is bound by laws and thus to its level of judicial dimension governance.

Many empirical studies have drawn on the WGI since its launch in 1999 to investigate the relationship between governance and economic growth (Dollar \& Kraay, 2003; Kaufmann \& Kraay, 2002; Naudé, 2004; Méon \& Sekkat, 2005). The WGI also has been widely used by international aid agencies as the basis for their policy decision making. However, some researchers have been critical of the WGI, citing its technical limits and erroneous application (Arndt \& Oman, 2006; Thomas, 2010; Kurtz \& Schrank, 2007; Arndt, 2008; Langbein \& Knack, 2010). In spite of its limitations, the WGI is still the most commonly used indicator in comparative research because of the wide number of countries and times periods it covers. Even though we have used the 
WGI to carry out our comparative cross-national study on governance in developing countries, we acknowledge the reservations others have expressed, and we exercise caution in our interpretation of the relevant statistical results.

\section{Independent and Control Variables}

The independent variable used in this study is the amount of aid intended for governance improvement by sector. Most past research on aid effectiveness used the ratio of aid to gross national product (or gross national income) as the independent variable and treated its relationship to economic growth rate as the dependent variable. However, this study aims to analyze whether each sector achieve its original policy goal as a result of receiving aid, and therefore we used the amount of aid channeled into each of the three sectors as an explanatory variable. In addition, in order to analyze the effect of aid on governance, we used the specific aid amounts spent by sector instead of the total amount of aid awarded and then examined the level of governance improvements in each corresponding area.

According to OECD Development Assistance Committee standards, the amounts of aid provided by donor countries can be refined by sector. In our first model, to measure aid intended for improving political institutions, we used the amount of aid designated for expanding ordinary citizens' political engagement via democratic elections. In the second model, we used the amount of aid allotted for public sector policy and administrative management to assess how such aid has contributed to improving the functioning of administrative institutions. In the third model, we used the amount of aid given for legal and judicial development to assess the level of judicial governance. The aid amounts have been extracted from international development statistics provided by the OECD's Development Assistance Committee.

To control for socioeconomic factors in different countries, we included GDP per capita, an indicator that represents the level of a country's economic development, and trade openness, that is, exports and imports as percentage of GDP. According to previous studies, economic development is engendered by a higher level of governance (Kaufmann et al., 1999), and the greater the role of the government becomes, the faster its institutionalization progresses. Furthermore, it is typically assumed that when a country's economy is opened up, its governance improves because of the country's awareness of the need to preserve its reputation among the countries it trades with (Rajan \& Zingales, 2003). Finally, population has also been included in the list of control variables as means of taking into account the different size of countries.

The research covered 90 developing countries over a 10-year period from 2002 to 2011 (the country list is supplied in appendix table 1). This particular time period was 
Table 1. Summary of Variables

\begin{tabular}{|c|c|c|}
\hline Variables & $\begin{array}{l}\text { Operational Definitions } \\
\text { and Measurement }\end{array}$ & Sources \\
\hline \multicolumn{3}{|c|}{ Dependent Variables: Governance } \\
\hline $\begin{array}{l}\text { political governance: } \\
\text { voice and accountability }\end{array}$ & $\begin{array}{l}\text { level of ordinary people's political } \\
\text { engagement; degree of freedom of } \\
\text { expression, assembly, and speech; } \\
\text { and politicians' accountability and } \\
\text { representativeness }\end{array}$ & $\begin{array}{l}\text { Kaufmann, Kraay and } \\
\text { Mastruzzi, } 2011\end{array}$ \\
\hline $\begin{array}{l}\text { administrative governance: } \\
\text { government effectiveness }\end{array}$ & $\begin{array}{l}\text { policy making and implementation } \\
\text { capacity to achieve policy goals } \\
\text { effectively (measured through the } \\
\text { quality of public service, public } \\
\text { servants, and policy formation and } \\
\text { execution along with the degree of } \\
\text { trust in policy execution) }\end{array}$ & \\
\hline $\begin{array}{l}\text { judicial governance: } \\
\text { rule of law }\end{array}$ & $\begin{array}{l}\text { degree of institutions' compliance with } \\
\text { the law and contract implementation, } \\
\text { degree of protection of property rights, } \\
\text { and quality of judicial institutions and } \\
\text { law enforcement agencies }\end{array}$ & \\
\hline
\end{tabular}

\section{Independent Variables: Amount of Aid by Sector}

\begin{tabular}{l|l|l}
\hline $\begin{array}{l}\text { aid for elections } \\
\begin{array}{l}\text { aid for public sector policy and } \\
\text { administrative management }\end{array}\end{array}$ & $\begin{array}{l}\text { amount of aid offered in relation to } \\
\text { election systems (log) } \\
\text { reforms in the public sector (log) }\end{array}$ & $\begin{array}{l}\text { OECD Development } \\
\text { Assistance Committee } \\
\text { n.d. }\end{array}$ \\
\hline $\begin{array}{l}\text { aid for legal and judicial } \\
\text { development }\end{array}$ & $\begin{array}{l}\text { amount of aid offered for } \\
\text { improvements in the area of judicial } \\
\text { institutions (log) }\end{array}$ & \\
\hline Control Variables & GDP per capita (log) & World Bank 2012 \\
\hline GDP per capita & $\begin{array}{l}\text { exports and imports percentage as } \\
\text { GDP (\%) }\end{array}$ & \\
\hline $\begin{array}{l}\text { trade openness } \\
\text { government expenditures }\end{array}$ & $\begin{array}{l}\text { government expenditure percentage } \\
\text { as GDP (\%) }\end{array}$ & \\
\hline population & total population (log) & \\
\hline
\end{tabular}


selected because the implementation of the MDGs was followed by significant increases in aid for governance improvements. Table 1 summarizes the independent, dependent, and control variables. The basic statistics of each variable are provided in appendix table 2 .

\section{EFFECT OF AID ON GOVERNANCE IMPROVEMENT}

We conducted empirical analyses to examine the effect of international aid on the level of recipient's governance in the three sectors. Table 2 shows the results of these analyses. Model 1 addressed the question of whether the amount of aid disbursed for reforming election processes has improved governance in the area of politics, which was measured by indicators for political participation and accountability. The result shows that the relationship between the two is weakly positive, which means that aid to political institutions does improve political governance, but the effect is not practically significant.

This weakly significant relation is in line with arguments that donor-supported aid for civic education programs intended to enhance political involvement, such as election participation, has some meaningful effects but is less likely to advance the fundamental values of democracy, such as trust and political tolerance (Finkel, 2014). This suggests that the magnitude of aid effectiveness is likely to depend on the design of the aid program and the quality of the trainers and that genuine improvement in political governance requires a long-term plan for embedding fundamental democratic values in developing countries. Aid programs and their delivery system also need to be designed properly, the political context in each country being carefully considered.

Model 2 analyzed to what extent the amount of aid intended for administrative reforms affected the governance indicator measuring administrative effectiveness. The result shows that as the amount of aid for administrative functions increases, the administrative governance indicator improves. It can be assumed that the effect of international aid for improving the administrative sector is relatively strong in comparison to that for political and judicial governance.

The positive effect of international aid targeted at improving administrative governance accords with many case studies about successful civil service reform (Scott, 2011). For example, Bolivia and Russia were successful in reforming their civil services via donor-supported aid programs that were created after obstacles to progress in the public and political sectors had been identified (Repucci, 2014). Moreover, Albania is reported to have carried out a successful civil reform using international aid to recruit civil servants (SIDA, 2009; Scott, 2011). 
Table 2. Aid and Governance Improvement (Panel Fixed Effect Model)

\begin{tabular}{|c|c|c|c|}
\hline & $\begin{array}{c}\text { Model } 1 \\
\text { Political } \\
\text { Governance } \\
\beta \\
\text { (Standard Error) }\end{array}$ & $\begin{array}{c}\text { Model } 2 \\
\text { Administrative } \\
\text { Governance } \\
B \\
\text { (Standard Error) }\end{array}$ & $\begin{array}{c}\text { Model } 3 \\
\text { Judicial } \\
\text { Governance } \\
\beta \\
\text { (Standard Error) }\end{array}$ \\
\hline aid for election ( $t-1$ ) & $\begin{array}{l}0.007^{*} \\
(0.004)\end{array}$ & & \\
\hline aid for public management (t-1) & & $\begin{array}{l}0.014^{* *} \\
(0.006)\end{array}$ & \\
\hline $\begin{array}{l}\text { aid for legal and judicial } \\
\text { development (t-1) }\end{array}$ & & & $\begin{array}{l}-0.009^{*} \\
(0.005)\end{array}$ \\
\hline GDP per capita (log) & $\begin{array}{l}0.143^{*} \\
(0.078)\end{array}$ & $\begin{array}{l}0.372^{\star * \star} \\
(0.056)\end{array}$ & $\begin{array}{l}0.279^{* * *} \\
(0.058)\end{array}$ \\
\hline trade openness (\%) & $\begin{array}{l}0.002^{* \star} \\
(0.001)\end{array}$ & $\begin{array}{l}-0.001^{\star *} \\
(0.000)\end{array}$ & $\begin{array}{l}0.000 \\
(0.000)\end{array}$ \\
\hline government consumption (\%) & $\begin{array}{l}-0.000 \\
(0.004)\end{array}$ & $\begin{array}{l}0.009^{\star * *} \\
(0.003)\end{array}$ & $\begin{array}{l}0.002 \\
(0.003)\end{array}$ \\
\hline population (log) & $\begin{array}{l}-0.364^{* *} \\
(0.158)\end{array}$ & $\begin{array}{l}-0.457^{* * *} \\
(0.118)\end{array}$ & $\begin{array}{l}-0.431^{* * *} \\
(0.126)\end{array}$ \\
\hline constant & $\begin{array}{l}7.670^{\star \star *} \\
(2.252)\end{array}$ & $\begin{array}{l}7.187^{* \star} \\
(1.665)\end{array}$ & $\begin{array}{l}7.806^{* \star \star} \\
(1.810)\end{array}$ \\
\hline observations & 536 & 765 & 732 \\
\hline group & 87 & 90 & 92 \\
\hline adjusted r-squared & 0.024 & 0.037 & 0.065 \\
\hline
\end{tabular}

Note: Standard error in parenthesis. ${ }^{* * *} p<0.01,{ }^{* *} p<0.05,{ }^{*} p<0.1$,

Note: A VIF test was conducted to verify multicollinearity between explanatory variables, which confirmed that there does not appear to be a high correlation among variables. We used the panel fixed-effect model because it is more consistent in controlling for unobservable factors in individual countries. It also confirmed via Hausman test that it provides more consistent estimators compared to the randomeffect model.

However, model 3, which analyzed the judicial sector, showed that the rule of law did not improve even when the amount of aid intended for judicial reform was increased, contrary to the hypothesis. This result is somewhat surprising given that international organizations have recently devoted more attentions and resources to the judicial sector than to the others. Considering the conservative culture of judicial sector in general, this result perhaps indicates that international donors have to reconsider the strategies they have developed to reform the recipient's legal or judicial system.

In order to test our results, we also replaced our original control variables with 
alternative ones, though we do not report the details in this paper. For example, we replaced GDP per capita with the GDP growth rate, which is mainly used in development economics. The results showed that aid affects governance improvement in the political and administrative dimension but not in the judicial dimension. We also analyzed another model that used variables normalized for population, including trade openness and government expenditures divided by population. In this model, we found again that when the amount of aid increased, political and administrative governance improved but not judicial governance. We received similar results after we used a lagged variable representing the amount of aid two years earlier $(t-2)$. Results showed a positive relation between the indicators for political and administrative governance and aid amount, although only the indicator for administrative governance was statistically significant, and a negative relation between judicial governance and aid amount.

In sum, these results indicate that although the expected improvements in political and administrative governance occur, they do not occur in the judicial sector. Previous research drawing on theories positing aid dependency and aid fungibility (which refers to the possibility of less developed countries using foreign aid for purposes other than those for which the aid programs were originally intended) has suggested that aid does not help improve governance. These studies gave rise to suspicions about aid effectiveness, which in turn has led to mistrust of the governments of developing countries among international donors. However, our results show that aid cannot be said to be generally ineffective but is instead only ineffective in specific with respect to judicial governance.

\section{DISCUSSION: EFFECTIVE AND EFFICIENT STRATEGIES FOR GOVERNANCE IMPROVEMENT}

Based on our results, first, we can suggest that strategies for governance improvement that focus on making particular sectors more effective can be designed. We found that administrative reform has been more successful than reform in the other areas. Comparing the value of the coefficients in models 1 and 2, we can see that the effect of aid on both political and administrative governance was positive, but the coefficient values in model 2 are larger. We can thus cautiously assume that aid is most helpful in the area of public administration. One possible explanation for this is that most of the administrative reform programs developed by international organizations focus on public financial management reform, budget accounting reform, and revenue expansion, and it may be easier to carry out these kinds of reforms in the short term. On the other hand, it takes much longer to cultivate political accountability, 
which is the goal of political governance improvements that the establishment of election systems is meant to achieve. However, the difference between the impact of aid in these two areas needs to be clarified further, of course. Are the more visible improvements in the area of public administration the result of an inherent difference between the sectors or were the aid programs that targeted public management reform carried out more effectively? Future studies need to explore how aid has been disbursed in each sector, what kinds of specific programs can be found in recipient countries, and how recipient countries have implemented programs.

That our analysis shows that aid programs for administrative reform are more effective than aid programs for reforms in the other sectors should also remind us of our forgotten premise. Even though the theory that public administration reform could significantly contribute economic and social development in developing countries was amply confirmed in 1960s and 1970s (Siffin, 1976; Riggs, 1970), since the 2000s, aid programs have shifted their focus from the administrative to the judicial sector. In the 1950s and 1960s, it was thought that the state should be the driving force behind their national development. However, in the second half of the 1970s, empirical studies gave rise to pessimism about the ability of state to effectively carry out their own development due to the corruption, violence, and political repression of developing countries' authoritarian regimes (Collier et al., 1979). In the wake of these studies, international organizations began to limit developing countries' administrative intervention through structural adjustment programs. Although renewed attention was paid to systems of governance in developing countries in reaction to the lost decade of development in the 1980s, since the 2000s, more emphasis has been put on judicial governance. As shown in Figure 1, the proportion of aid allotted for administrative governance reform has been decreasing while that for judicial governance reform has been increasing. The results of our study provide meaningful evidence for turning attention back to role of public administration once again. Our study suggests administrative governance should receive priority when it comes to deciding which area of governance would most benefit from aid.

Second, the results of our study indicate that donor organizations need to consider new ways of governance reform in the judicial sector that take into account the specific context of each developing country. It is the rule of law that has been mostly emphasized by international organizations in their promotion of good governance. Given the large amount of aid that has been awarded for the implementation of good governance (see Figure 1), it is quite paradoxical that judicial reforms have not been effective. The failure of these reforms may be a function of the nature of technical assistance programs for legal and judicial development, which are mainly aimed at implementing pilot programs that provide judicial training so as to enhance the effectiveness of the judiciary and 
Figure 1. Aid Amount by Governance Dimensions (\$USD million)

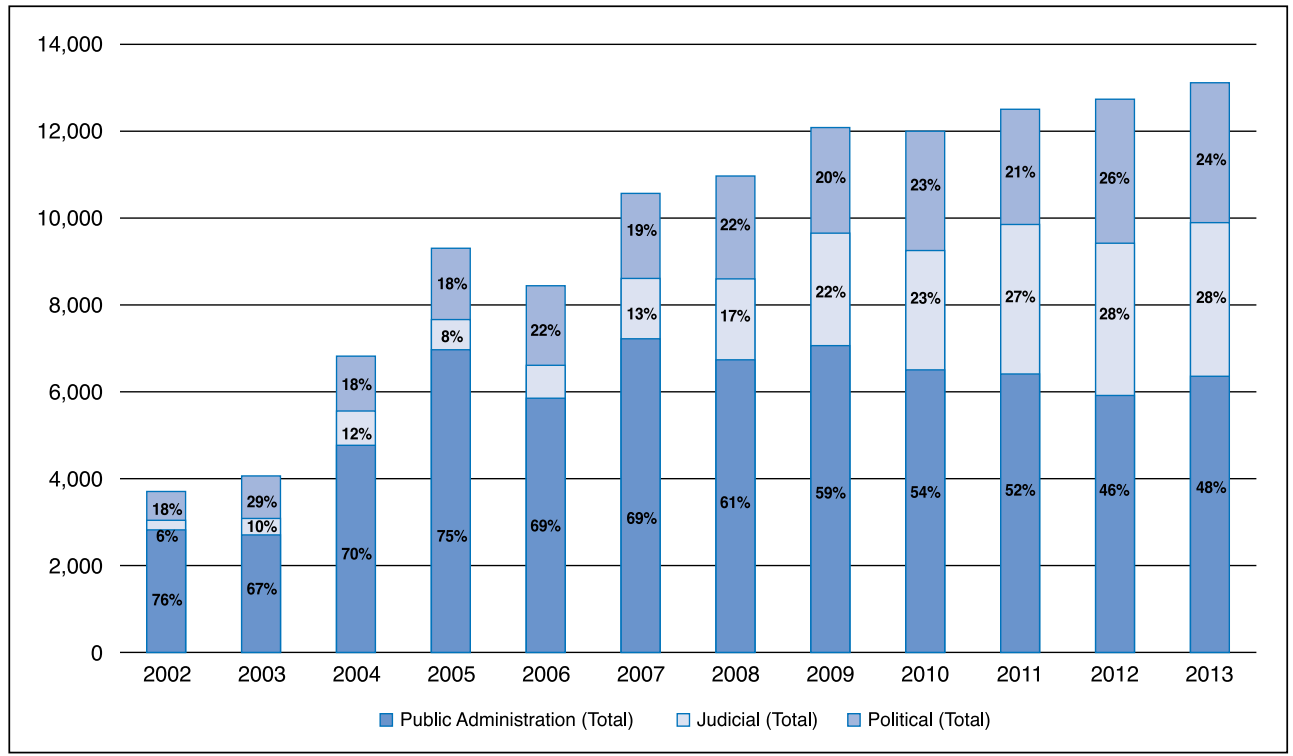

make it possible for developing countries to draft economic legislation (World Bank, 2006). However, it is unrealistic to expect noteworthy improvement in the short term through the imposition by the global North of the idea of the rule of law on the global South. As studies on corruption and the rule of law in developing countries have shown, each nation has its own common practices that derive from its particular social, historical and cultural background, and therefore the integration of the idea of the rule of law into these nations may take time (Khan, 2006). Research on social capital also points out that the accumulation of social capital can lead to improvements in the judicial systems of developing countries (La Porta et al., 2000). However, it likewise takes a considerable amount of time to accumulate social capital. Therefore, those who expect to see governance improvements in a developing country's judicial sector through aid must approach the issue by bearing in mind that unique historical and cultural backgrounds as well as political and socioeconomic circumstances need to be taken into account and that it will take time for any visible impact of foreign aid to be observed. 


\section{CONCLUSION}

Since the start of the new millennium, a number of bilateral and multilateral organizations in international development have been increasing the amount of aid targeting governance improvements in recipient countries. Our study presents an empirical analysis of the relationship between foreign aid and governance improvements with the aim of exploring whether such aid has indeed facilitated improvements of governance in the developing world.

Some previous studies that evaluated individual programs reported that most of the reforms were successful, whereas others pointed to failure to achieve goals. Still other empirical studies, drawing on aid dependency theory, contended that the more aid a country receives, the less its government tends to make any attempts of its own to advance the country and that, more often than not, governance does not improve. Analyzing the relationship between governance and aid in political, administrative and judicial sectors, we found that aid has helped to improve governance in the areas of politics and public administration but has not led to any notable improvements of judicial governance. In addition, compared to the improvements observed in public administration, the improvements in the political sector are less impressive.

These results have interesting policy implications for both donor agencies and developing countries. Donor agencies have placed much more emphasis on establishing the rule of law in developing countries than on reforming their political and judicial systems, but there has not been much progress. International organizations have imposed policies on the global South that derive from the past experience of advanced countries in the global North. However, simply benchmarking other countries' successes or attempting to implant relevant policy schemes does not ensure the easy adoption of the rule of law in a developing country. This is a challenge that can only be addressed by coming to a genuine understanding of the specific situation of a developing country. Such a mandate should be considered for the future agenda of international development.

Up until now, evaluation of aid programs had been limited to an analysis of individual programs, making a comprehensive view of aid effectiveness by sector or by nation difficult to achieve. We have attempted to remedy that by offering an empirical study that uses the nation as the level of analysis. Nevertheless, one shortcoming is that we were unable to uncover the internal dynamics that would reveal how specific aid programs ultimately lead to change in each governance sector. Future case studies could complement our work by exploring the mechanisms by which international aid improves governance in each sector in the recipient countries. 


\section{REFERENCES}

AbouAssi, K. 2010. International development management through a Southern lens. Public Administration and Development, 30(2): 116-123.

Acemoglu D., Simon, J., \& James, A. R. 2001. The colonial origins of comparative development: An empirical investigation. American Economic Review, 91(5): 1369-1401.

Arndt, C. 2008. The politics of governance ratings. International Public Management Journal, 11(3): 275-297.

Arndt, C., \& Oman, C. 2006. Uses and abuses of governance indicators. Paris: OECD.

Bräutigam, D. A., \& Knack, S. 2004. Foreign aid, institutions, and governance in subSaharan Africa. Economic Development and Cultural Change, 52(2): 255-285.

Brinkerhoff, D. W. 2008. The state and international development management: Shifting tides, changing boundaries, and future directions. Public Administration Review, 68(6): 985-1001.

Brinkerhoff, J. M., \& Brinkerhoff, D. W. 2002. Government-nonprofit relations in comparative perspective: Evolution, themes and new directions. Public Administration and Development, 22(1): 3-18.

Brinkerhoff, J. M., \& Brinkerhoff, D. W. 2010. International development management: A Northern perspective. Public Administration and Development, 30(2): 102-115.

Busse, M., \& Gröning, S. 2009. Does foreign aid improve governance? Economics Letters, 104(2): 76-78.

Choi, B.-S. 2006. Regulation theory and policy in the context of new institutional economics: Disputes and expansions. Korean Journal of Public Administration, 44(2): 179-216.

Denhardt, J. V., \& Denhardt, R. B. 2007. The new public service: Serving, not steering. Armonk, NY: M. E. Sharpe.

Denhardt, R. B., \& Denhardt, J. V. 2000. The new public service: Serving rather than steering. Public Administration Review, 60(6): 549-559.

Dichter, T. W. 2003. Despite good intentions: Why development assistance to the third world has failed. Amherst: University of Massachusetts Press.

Dollar, D., \& Kraay, A. 2003. Institutions, trade, and growth. Journal of Monetary Economics, 50(1): 133-162.

Doornbos, M. 2001. "Good governance": The rise and decline of a policy metaphor? The Journal of Development Studies, 37(6): 93-108.

Easterly, W. 2006. The white man's burden: Why the West's efforts to aid the rest have done so much ill and so little good. New York: Penguin.

Escobar, A. 1995. Encountering development: The making and unmaking of the third 
world. Princeton, NJ: Princeton University Press.

Finkel, S. E. 2014. The impact of adult civic education programmes in developing democracies. Public Administration and Development, 34(3): 169-181.

Gray, H., \& Khan, M. 2010. Good governance and growth in Africa: What can we learn from Tanzania? In V. Padayachee (ed.), The political economy of Africa (pp. 339-356). London: Routledge.

Hewitt de Alcántara, C. 1998. Uses and abuses of the concept of governance. International Social Science Journal, 50(155): 105-113.

Hyden, G. 1999. Governance and the reconstitution of political order. In R. Joseph (ed.), State, conflict, and democracy in Africa. Boulder, CO: Lynne Rienner.

Johnson, C. 1999. The developmental state: Odyssey of a concept. In M. Woo-Cumings (ed.), The developmental state. Ithaca, NY: Cornell University Press.

Johnson, D., \& Zajonc, T. 2006. Can foreign aid create an incentive for good governance? Evidence from the Millennium Challenge Corporation. John F. Kennedy School of Government, Harvard University.

Joost, T. 2007. Good governance as a discursive strategy — analysis of the policy discourse in the Netherlands and Germany. The Netherlands Yearbook on International Cooperation. Assen: Royan Van Gorcum.

Kaufmann, D., \& Kraay, A. 2002. Growth without governance. Economia, 3(1): 169-229.

Kaufmann, D., Kraay, A., \& Pablo, Z.-L. 1999. Governance matters. World Bank Policy Research Working Paper No. 2196. Washington, DC: World Bank.

Kaufmann, D., Kraay, A., \& Mastruzzi, M. 2011. Worldwide governance indicator. Retrieved on December 18, 2012, from /www.govindicators.org.

Kettl, D. F. 2002. The transformation of governance: Public administration for twentyfirst-century America. Baltimore, MD: Johns Hopkins University Press.

Khan, M. 2006. Governance and anti-corruption reforms in developing countries: Policies, evidence and ways forward. G-24 Discussion Paper. Geneva: United Nations Conference on Trade and Development.

Kim, E. 2013. Does governance matter for poverty reduction? Analysis of quantitative evidence from 98 developing countries. Graduate School of Public Administration, Seoul National University.

Knack, S. 2001. Aid dependence and the quality of governance: Cross-country empirical tests. Southern Economic Journal, 68(2): 310-329.

Knack, S., \& Keefer, P. 1995. Institutions and economic performance: Cross-country tests using alternative institutoioal measures. Economics and Politics, 7(3): 207-227.

Knoll, M., \& Zloczysti, P. 2012. The good governance indicators of the millennium challenge account: How many dimensions are really being measured? World 
Development, 40(5): 900-915.

Kurtz, M. J., \& Schrank, A. 2007. Growth and governance: Models, measures, and mechanisms. Journal of Politics, 69(2): 538-554.

Kwon, H.-J., \& Kim, E. 2014. Poverty reduction and good governance: Examining the rationale of the millennium development goals. Development and Change, 45(2): 353-375.

Kwon, H. J. 2010. Implications of Korea's saemaul undong for international development policy: A structural perspective. Korean Journal of Policy Studies, 25(3): 87-100.

La Porta R., Lopez-de Silanes, F., Shleifer, A., et al. 2000. Trust in large organizations. In P. Dasgupta \& I. Serageldin (eds.), Social capital: A multifaceted perspective. Washington, DC: World Bank.

Langbein, L., \& Knack, S. 2010. The worldwide governance indicators: Six, one, or none? Journal of Development Studies, 46(2): 350-370.

Leftwich, A. 1994. Governance, the state and the politics of development. Development and Change, 25(2): 363-386.

Méon. P.-G., \& Sekkat, K. 2005. Does corruption grease or sand the wheels of growth? Public Choice, 122(1-2): 69-97.

Moyo, D. 2009. Dead aid: Why aid is not working and how there is a better way for Africa. New York: Farrar, Straus and Giroux.

Naudé, W. A. 2004. The effects of policy, institutions and geography on economic growth in Africa: An econometric study based on cross-section and panel data. Journal of International Development, 16(6): 821-849.

North, D. C. 1990. Institutions, institutional change, and economic performance. Cambridge: Cambridge University Press.

OECD Development Assistance Committee. N.d. International development statistics. Retrieved on on September 6, 2013, from www.oecd.org/dac/stats/idsonline.htm.

Pierre, J., \& Peters, B. G. 2000. Governance, politics, and the state. New York: St. Martin's Press.

Rajan, R. G., \& Zingales, L. 2003. The great reversals: The politics of financial development in the twentieth century. Journal of Financial Economics, 69(1): 5-50.

Repucci, S. 2014. Designing effective civil service reform lessons from past experience. Public Administration and Development, 34(3): 207-218.

Riggs, F. W. 1970. Frontiers of development administration. Durham, NC: Duke University Press.

Rodrik D., Subramanian, A., \& Trebbi, F. 2004. Institutions rule: The primacy of institutions over geography and integration in economic development. Journal of Economic Growth, 9(2): 131-165.

Scott, Z. 2011. Evaluation of public sector governance reforms 2001-2011: Literature 
review. Oxford, UK: Oxford Policy Management.

SIDA. 2009. Sida's support for capacity development in the public administration of partner countries. Stockholm: Swedish International Development Cooperation Agency.

Siffin, W. J. 1976. Two decades of public administration in developing countries. Public Administration Review, 36(1): 61-71.

Thomas, M. A. 2010. What do the worldwide governance indicators measure? European Journal of Development Research, 22(1): 31-54.

Unsworth, S. 2009. What's politics got to do with it? Why donors find it so hard to come to terms with politics, and why this matters. Journal of International Development, 21: 883-894.

Utz, R. 2007. Sustaing and sharing economic growth in Tanzania. Washington, DC: World Bank.

World Bank. 2001. PRSP source book. Washington, DC: World Bank.

World Bank. 2006. Republic of Yemen: Legal and judicial development project. Project Performance Assessmnet Report.

World Bank. 2012. World development indicators 2012. Retrieved on August 12, 2013, from http://databank.worldbank.org. 
Appendix Table 1. Country List (90 Developing Countries)

\begin{tabular}{l|l}
\hline \multicolumn{1}{c|}{ Region } & \multicolumn{1}{c}{ Country } \\
\hline Asia and Pacific (8) & $\begin{array}{l}\text { Cambodia, Fiji, Indonesia, Lao PDR, Malaysia, Philippines } \\
\text { Thailand, Vietnam }\end{array}$ \\
\hline $\begin{array}{l}\text { Europe and Central } \\
\text { Asia (14) }\end{array}$ & $\begin{array}{l}\text { Albania, Armenia, Azerbaijan, Belarus, Bosnia and Herzegovina, } \\
\text { Georgia, Kazakhstan, Kyrgyz Republic, Macedonia, Moldova, } \\
\text { Montenegro, Serbia, Tajikistan, Ukraine }\end{array}$ \\
\hline $\begin{array}{l}\text { Latin America and the } \\
\text { Caribbean (20) }\end{array}$ & $\begin{array}{l}\text { Argentina, Bolivia, Brazil, Chile, Colombia, Comoros, Costa Rica, } \\
\text { Dominican Republic, Ecuador, El Salvador, Guatemala, Honduras, } \\
\text { Jamaica, Mexico, Nicaragua, Panama, Paraguay, Peru, Uruguay, } \\
\text { Venezuela }\end{array}$ \\
\hline Middle East and & Egypt, Iran, Jordan, Morocco, Syria, Tunisia, Turkey, Yemen \\
\hline South Asrica (8) & Bangladesh, Bhutan, Nepal, Pakistan, Sri Lanka \\
\hline sub-Saharan Africa & $\begin{array}{l}\text { Benin, Burkina Faso, Burundi, Cameroon, Cape Verde, Central } \\
\text { African Republic, Chad, Congo, Rep., Cote d'Ivoire, Djibouti, } \\
\text { Ethiopia, Gabon, Gambia, Ghana, Guinea, Kenya, Lesotho, } \\
\text { Liberia, Madagascar, Malawi, Mali, Mauritania, Mozambique, } \\
\text { Namibia, Niger, Rwanda, Senegal, Sierra Leone, South Africa, } \\
\text { Sudan, Swaziland, Tanzania, Togo, Uganda, Zambia }\end{array}$ \\
\hline
\end{tabular}

Appendix Table 2. Basic Statistics

\begin{tabular}{|c|c|c|c|c|c|}
\hline Variable & Observations & Mean & $\begin{array}{l}\text { Standard } \\
\text { Deviation }\end{array}$ & Minimum & Maximum \\
\hline \multicolumn{6}{|l|}{ Dependent Variables } \\
\hline voice and accountability & 900 & 3.04 & 0.66 & 1.68 & 4.74 \\
\hline government effectiveness & 900 & 3.02 & 0.55 & 1.71 & 4.77 \\
\hline rule of law & 900 & 2.93 & 0.53 & 1.64 & 4.87 \\
\hline \multicolumn{6}{|l|}{ Independent Variables } \\
\hline aid for elections (t-1) & 554 & 13.20 & 2.09 & 6.16 & 18.63 \\
\hline $\begin{array}{l}\text { aid for public management } \\
\text { (t-1) }\end{array}$ & 803 & 16.24 & 1.41 & 11.40 & 19.49 \\
\hline $\begin{array}{l}\text { aid for legal and judicial } \\
\text { development (t-1) }\end{array}$ & 767 & 14.48 & 1.82 & 6.11 & 18.97 \\
\hline \multicolumn{6}{|l|}{ Control Variables } \\
\hline GDP per capita (log) & 883 & 7.99 & 0.94 & 5.75 & 9.63 \\
\hline trade openness ( $\%$ of GDP) & 883 & 80.99 & 35.70 & 21.67 & 210.37 \\
\hline $\begin{array}{l}\text { government consumption } \\
\text { (\% of GDP) }\end{array}$ & 875 & 13.92 & 5.53 & 3.46 & 39.50 \\
\hline population (log) & 900 & 16.19 & 1.39 & 13.04 & 19.31 \\
\hline
\end{tabular}

*Note: The original WGI governance indicator ranges from -2.5 to +2.5 . However, since all values need to be positive numbers, all variables are scaled up by +3.5 . 